\title{
Investment for Competitive Power Plants under Uncertainty of Allocation Scheme*
}

\author{
Junichiro Oda ${ }^{\mathrm{a}}{ }^{\dagger}$ and Ryuta Takashima ${ }^{\mathrm{b}}$ \\ a Systems Analysis Group, Research Institute of Innovative Technology for the Earth (RITE) \\ b Faculty of Social Science, Chiba Institute of Technology
}

\begin{abstract}
In this study we focus on power generation replacement and CCS investment as a substitute for an aged coal-fired power plant under an emission trading system. In this analysis carbon price, gas price and free allocation are explicitly uncertain. Using a real options approach we evaluate the thresholds between "waiting" and "investment right now". The results indicate that it requires substantially higher carbon price for early CCS diffusions. For example, in the case of middle-range gas price (around US\$8/GJ), US\$65/ $\mathrm{tCO}_{2}$ is not sufficiency to invest CCS right now. In addition allocation uncertainty makes it more difficult to diffuse CCS in an early stage.
\end{abstract}

Keywords: Carbon capture and storage; cap and trade; free allocation; replacement; aged coal-fired power plant

\footnotetext{
${ }^{*}$ Received: June 29, 2010; Accepted: January 25, 2011.

${ }^{\dagger}$ Corresponding author. Address: 9-2 Kizugawadai, Kizugawa-shi, Kyoto 619-0292, Japan; Phone: +81774-75-2304; E-mail: jun-oda@rite.or.jp
} 


\title{
キャップ割当スキームの不確実性が電源投資に与える影響評価
}

\author{
小田 潤一郎 ${ }^{a}$, 高嶋 隆太 ${ }^{b}$ \\ a (財) 地球環境産業技術研究機構 (RITE) システム研究グループ \\ $\mathrm{b}$ 千葉工業大学 社会システム科学部
}

\section{1 はじめに}

\section{1 キャップ・アンド・トレードに関する背景}

温暖化政策を議論・検討するにあたっては，設備の更新や各種投資の意思決定主体である一 企業の視点も考慮することが政策の実効性といった意味で重要である．温暖化政策（国内）の メニューは税, キャップ・アンド・トレード, 規制, 自主行動, 補助金, 毭賞, 研究開発など 多岐に渡るが，中でもキャップ・アンド・トレードの実証的側面については，とりわけ多様な 議論がなされている [12]. 諸富・鮎川 [17] は理論的にも実証的にもキャップ・アンド・トレー ドの有効性を主張する一方, 岡・山口 [13], 杉山 [15] は実証的側面に注目し欧州排出権取引制 度 (EUETS) のフェーズ III までの動向・議論を調査しつつ, 「キャップ・アンド・トレード」は 「キャップ\&キャップ\&...」という政府・企業間のキャップをめぐる繰り返しゲームであるとし ている，つまり，ここでの問題意識は， $\mathrm{CO}_{2}$ 削減を行わないと多くの無償キャップを得る可能 性がある一方, $\mathrm{CO}_{2}$ 削減の投資を行うと無償キャップが切り下げられる可能性があり, 従って 「キャップ・アンド・トレード」が $\mathrm{CO}_{2}$ 削減の投資を誘発すると単純には言えないというもの である。

EUETS は，過去の排出実績に基づく「グランドファザリング」から効率指標を参照する「べ ンチマーク」(以上が無償割当), そして「有償オークション」へ移行する計画としていた。た だし，国際競争力への懸念などを背景として，「有償オークション」への移行はより遅らせるこ ととしている．杉山 [15] は,「有償オークション」への移行は公式アナウンスとは異なり現実 に進みにくく，無償キャップを巡るゲームが今後とも続く可能性を指摘している．このように， キャップ・アンド・トレードを実施する場合, 企業は排出権価格のみならず，割当スキームの不 確実性すなわちキャップ水準の不確実性にさらされると言える.とりわけ電力, 鉄鋼, セメン トといった部門では設備の耐用年数が数十年と長期に渡るため, キャップ割当スキームの不確 実性は特に問題となると定性的に指摘されている $[15]$.

\section{2 炭素回収貯留 $(\mathrm{CCS})$ に関する背景}

具体的な温暖化対策手段として, IEA [6], IPCC [7] を含め長期的かつ量的に期待されてい るのはとりわけ原子力, 再生可能エネルギー及び CCS である. IEA [6] では, 2007 年（以下， 
現在と記載）比で 2050 年に世界の $\mathrm{CO}_{2}$ 排出量が倍増し $57 \mathrm{GtCO}_{2}$ となる Baseline シナリオと, 逆に 2050 年に現在比で世界の $\mathrm{CO}_{2}$ 排出量が半減し $14 \mathrm{GtCO}_{2}$ となる BLUE Map シナリオを 示している. 2050 年時点の Baseline シナリオでは石炭火力が現状比で 2.5 倍となっていたが, BLUE Map シナリオでは（CCS なしの）石炭火力はほぼ全廃となる. BLUE Map シナリオで は, 原子力, バイオマス (廃棄物含む), 風力, 太陽光などが石炭火力にとってかわり, これ らの発電電力量（世界計）は現在比で 2050 年にそれぞれ 3.5 倍 ${ }^{1}, 9.5$ 倍, 28 倍, 1,000 倍とな る (Baseline 比で計 $10 \mathrm{GtCO}_{2}$ の削減効果) 。これらだけでは $\mathrm{CO}_{2}$ 排出量の現在比半減に及ば ず，さらに CCS により $9.4 \mathrm{GtCO}_{2}$ を 2050 年時点で回収貯留する結果である（CCS の増エネ分 を加味した正味の削減量は $8.2 \mathrm{GtCO}_{2}$ ).

IPCC [7] においても，2070 年以降正味で負の排出となるパス（CCS に多くを依存）2を引用 しており，このような負の排出パスは結果的に社会へ強い影響を与えた ${ }^{3}$ 。このように, CCS について極めて高い期待がなされている一方, 現在のところ CCS の投資は量的に緩慢であ り, IEA [6]においても手厚い補助が必要とされている. その理由として主に次のような要因が 考えられる.

（i）（省エネ対策とは逆に）炭素回収を行うことで増エネ（発電効率の低下）となること．

(ii) $\mathrm{CO}_{2}$ 削減に伴う大きな利得がない場合, 初期投資に加え, さらにランニングコストも増 加すること（CCS は $\mathrm{CO}_{2}$ 削減以外の（副次的）便益を有しないため $\mathrm{CO}_{2}$ 特化対策とも 言われる)。

(iii) 炭素貯留については社会的側面や法整備上の課題があり, 何らかの理由により CCS の稼 働率低下/操業停止といったリスクがあること.

このように CCS について極めて高い期待がなされているものの, その現実的課題も同視野 に入れ各種検討を行うことが求められる状況と言える [3].

\section{3 目的及び実施内容}

以上を背景とし，本稿では電源更新，及び CCS 投資を検討している企業に注目しつつ，キャッ プ・アンド・トレードの施行下において, ガス価格, 排出権価格, キャップ水準の不確実性を 明示的に考慮しつつ, 待機と投資の閾值を算出することにより, 不確実性の影響が電源更新や CCS 投資にどのような影響を与えるか概観することを目的とする.

一般に CCS 投資が経済合理性を持つ炭素価格は $38\left(\mathrm{US} \$ / \mathrm{tCO}_{2}\right)[4]$ という説明がなされる が，これは確実性下での NPV 法に基づく閾值である. IEA [4] では炭素価格がジャンプする不

\footnotetext{
${ }^{1} 2050$ 年時点で世界の原子力による発電量が現状比 3.5 倍という比率は大幅な増加といってよく, 中国は 100 万 $\mathrm{kW}$ クラス換算で 312 基，インドでも同 122 基を保有することなどを積上げて算定している [6].

2 「正味で負の排出」とは，化石燃料の燃焼に伴う $\mathrm{CO}_{2}$ をほぼ全量回収貯留するのみならず，バイオマス（成長過 程で炭素吸収がなされたとみなされる）の燃焼に伴う $\mathrm{CO}_{2}$ も回収貯留することによって（理論的には）起こりうる.

${ }^{3} \mathrm{IPCC}$ 報告書自体には,「2070 年以降負の排出となるパスを IPCC は推奨する」,「産業革命以前比で気温上昇を 2 ${ }^{\circ} \mathrm{C}$ 未満に抑えることを IPCC は推奨する」といった記載は全くないものの，一部の IPCC 関係者の記者会見やメディ ア報道を通じてそのような認識が結果的に社会へ広まった [8].
} 
確実性を考慮すると $38\left(\mathrm{US} \$ / \mathrm{tCO}_{2}\right)$ の閾值は 6 $14\left(\mathrm{US} \$ / \mathrm{tCO}_{2}\right)$ 程度上昇することを示してい る.また炭素価格の不確実性に加えガス価格の不確実性を考慮した分析では，投資の閾值が数 十 $\left(\mathrm{US} \$ / \mathrm{tCO}_{2}\right)$ といったオーダーで上昇しうることを示している [14].これら既往の研究に対 し, 本稿ではキャップ・アンド・トレード施行下で個々の企業にととって関心が高いキャップ水 準の不確実性を明示的に考慮したことに特徵がある.

本稿では具体的に次のような分析を実施する. 分析対象とする企業は, 現在自家発設備（石 炭火力）劣保有しているが老朽化のため数年後に稼働を停止し, 新規電源に切り替える必要が あるとする．選択できる電源は新鋭の微粉炭火力かガス火力（コンバインドサイクル）とし，こ れらは共に炭素回収設備を付設することができる. 天然ガス価格（以下，ガス価格と記載）と 排出権価格（以下，炭素価格と記載）は確率過程に従うとの扱いとする. キャップ水準は比較 のため完全予見ケースと, 低確率ながらキャップ水準が過去の排出により設定される可能性の あるケースの 2 ケースを想定する. 目的関数は割引後の総期待費用の最小化とし, 数值計算に より待機・投資の閾值を解く.

\section{2 モデルの枠組み}

\section{1 分析対象とする企業の状況}

分析対象とする企業は次のような状況にあるものとする.

（i）これまで自家発設備（石炭火力）を運転することで自社グループ向けのベース電力を供給 してきたが，当自家発設備の経年化に伴い電源更新が必要となっている.

(ii) 電源更新にあたっては, 1) ガス火力, 2) ガス火力+CCS, 3) 石炭火力, 4) 石炭火力+CCS, といった 4 つの選択肢を持つ。 またこれら電源のリードタイムは比較的短い.

(iii) CCS を導入した場合, 石油増進回収 (EOR) 向けに $\mathrm{CO}_{2}$ が有償で利用され, $\mathrm{CO}_{2}$ 圧縮及 び輸送の総費用は $\mathrm{CO}_{2}$ 販売収入で相殺される（これは当企業が CCS 導入に有利な条件下 にいることを意味する ${ }^{5}$ )

(iv) キャップ・アンド・トレードが施行されており, 当企業にもキャップ割当がなされる（具 体的なキャップ水準の詳細については後述）.

（v）キャップ水準の不確実性に加え，ガス価格と炭素価格の不確実性に企業はさらされており これらを考慮したいと考えている.

\footnotetext{
4 とりわけ単位売上当りの $\mathrm{CO}_{2}$ 排出量の大きいエネルギー集約産業（電力部門，セメント部門，鉄鋼部門など）に おいて競合他社との間で衡平なキャップが将来に渡って課されるかどうかは，企業にとって重要である．なお，欧米諸 国ではキャップ・アンド・トレードといっても高々 $30\left(\mathrm{US} \$ / \mathrm{tCO}_{2}\right)$ 程度の炭素価格を念頭に議論されるが, 日本の場合 は低くても $50\left(\mathrm{US} \$ / \mathrm{tCO}_{2}\right)$ 以上, 場合によっては $100\left(\mathrm{US} \$ / \mathrm{tCO}_{2}\right)$ 以上の炭素価格が想定されるため, キャップの寡 多は死活問題と言える.

5 このような $\mathrm{EOR}$ 向けの $\mathrm{CO}_{2}$ 需要は米国の一部でローカルには見込めるが量的にそれほど大きくない点に注意が 必要である [11].
} 
（vi）設備容量及び稼働率は新旧設備で同一とする. 従って売電や系統電力の調達は予定してい ない（電力価格の不確実性は扱わない）。

(vii) 企業は今後 40 年間に渡り発生する総期待費用を最小化したいと考えている（企業はリス ク中立的とする）.

\section{2 タイムスケジュールとキャップ水準の設定}

分析開始時点を $t=0$ (年, 以下単位省略）とし, 現在稼働中の自家発設備（石炭火力）は $t=8$ までに稼働停止し新規電源へ代替する必要があるとする. 投資決定から稼働するまでの リードタイムをガス火力 (+CCS) は 2 年, 石炭火力 (+CCS) は 4 年とする [9]. 従って, 石 炭火力 $(+\mathrm{CCS})$ に投資するならば $t=4$ までに意思決定する必要があり, それ以降はガス火 力 $(+\mathrm{CCS})$ しか選択できない. また遅くとも $t=6$ には「ガス火力」か「ガス火力 $+\mathrm{CCS} 」 の$ どちらかを選択しなくてはならない. 逆に $t=0$ と同時にガス火力 $(+\mathrm{CCS})$ への投資を決定 することで最短で $t=2$ に既存石炭火力の稼働を停止し，新規電源への切り替えができる.

キャップ水準（無償割当）については比較のため次の 2 ケースを想定する.

(i) キャップ予見ケース： $0 \leq t<10$ は既存石炭火力稼働に伴い排出していた水準 $(1,081$ $\left.\mathrm{kgCO}_{2} / \mathrm{MWh}\right), 10$ 年目から 25 年目 $(10 \leq t<25)$ までは $540 \mathrm{kgCO}_{2} / \mathrm{MWh，そして} 25$ 年目 $(t=25)$ 以降はキャップがゼロとする.

(ii) キャップ不確定ケース： 10 年目から 25 年目 $(10 \leq t<25)$ のキャップが確率 0.3 で過去の 排出に基づき設定 6 される (グランドファザリング). ただし確率 0.7 で $540 \mathrm{kgCO}_{2} / \mathrm{MWh}$ となる．他， $t=10$ までと $t=25$ 以降は「キャップ完全予見ケース」と同一.

以上のタイムスケジュールを図 1 に示す.

\section{3 確率過程に従う項目}

確率過程に従う項目は，ガス価格と炭素価格とする. 天然ガス（米国井戸元価格）は 1986 年 から 1990 年代半ばまで石炭価格＋環境プレミアム (SOx など) という構造であり 2 (US\$/GJ) 前後を安定的に推移していたが，1990 年代半ば以降は原油価格との連動性を強め 2008 年夏季 には $12(\mathrm{US} \$ / \mathrm{GJ})$ 超に至った。その後急落したが現在は $4(\mathrm{US} \$ / \mathrm{GJ})$ とやや回復した $[10]^{7}$.

炭素価格について EUETS では 20〜30 $\left(\mathrm{US} \$ / \mathrm{tCO}_{2}\right)$ 相当を推移している. 将来見込みに関連 して，例えば 2050 年時点で現状程度の排出水準に戻すシナリオでは $30\left(\mathrm{US} \$ / \mathrm{tCO}_{2}\right)[16], 50$

6 「過去の排出に基づき設定」とは, 例えば石炭火力を事前に導入した場合その排出係数と同じ $828 \mathrm{kgCO}_{2} / \mathrm{MWh}$ の キャップ水準となることを意味する. ガス＋CCS を事前に導入した場合も同様にその排出係数である $40 \mathrm{kgCO}_{2} / \mathrm{MWh}^{2}$ となる.

7 ガス価格は従来から地域により差異がある。米国はシェールガスの影響などで直近はかなり低い価格推移となって おり 2009 年末から 2010 年 5 月にかけて井戸元価格は 4 5(US\$/GJ) 前後 [10]. これに対し 2009 年末の German border price は $8(\mathrm{US} \$ / \mathrm{GJ})$ 前後. 日本の $\mathrm{LNG}$ 輸入価格は元々下振れしない傾向にあり 2009 年から 2010 年 5 月 は $10(\mathrm{US} \$ / \mathrm{GJ})$ 前後 [9]. 

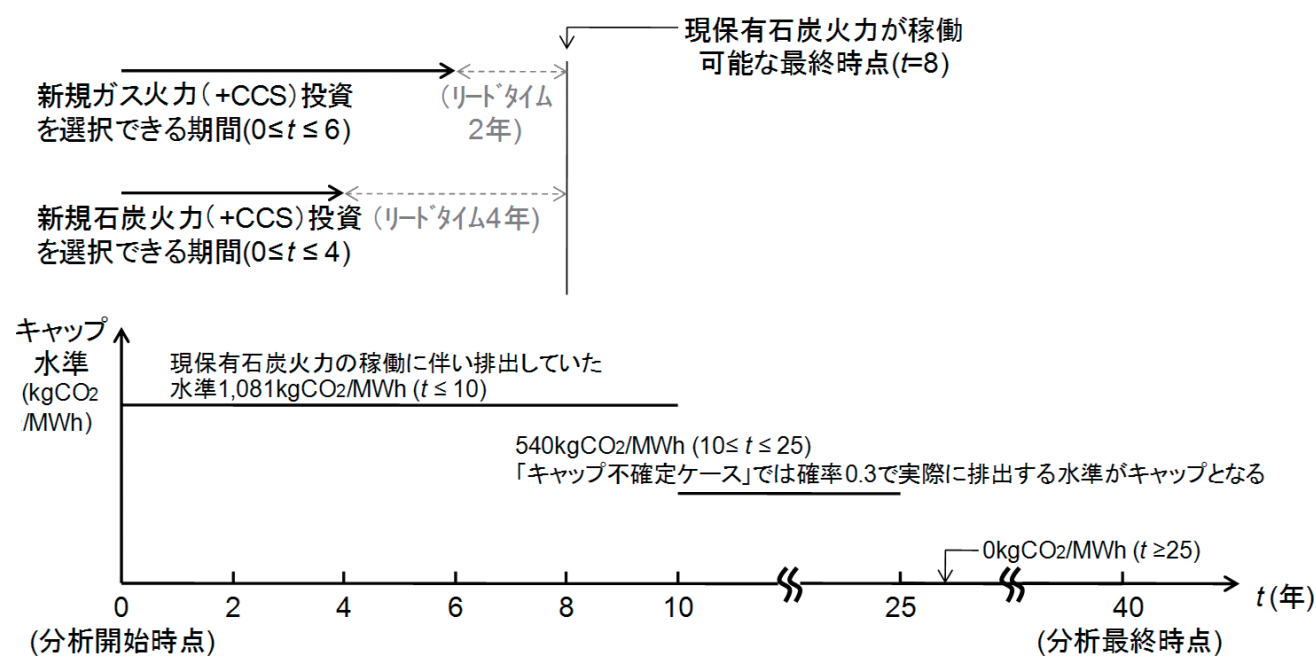

図 1: 分析のタイムスケジュール

〜 100(US\$ $\left./ \mathrm{tCO}_{2}\right)$ [5]，2050 年時点で現状比半減のシナリオでは $334\left(\mathrm{US} \$ / \mathrm{tCO}_{2}\right)$ [16], 200〜 $500\left(\mathrm{US} \$ / \mathrm{tCO}_{2}\right)$ (IEA[5]) とかなり幅広い.

本稿においてガス価格と炭素価格は（企業にとって平均回帰過程を採用するほど十分な確信 度を持てなかったとして）次の幾何ブラウン運動に従うとする.

$$
\begin{aligned}
& d P_{1}=a_{1} P_{1} d t+b_{1} P_{1} d z_{1} \\
& d P_{2}=a_{2} P_{2} d t+b_{2} P_{2} d z_{2}
\end{aligned}
$$

ただし, $a_{1}, a_{2}$ は $P_{1}, P_{2}$ の期待変化率, $b_{1}, b_{2}$ は $P_{1}, P_{2}$ のボラティリティ, $d z_{1}, d z_{2}$ はウィ ナ一過程の増分である.

\section{4 モデルの定式化と数值解法}

本ケースにおいて解析解は得られないため, 数值解に頼らざるを得ない。ここでは, ベルマ ン方程式を用いた動的計画法により数值的に待機・投資の閾值を求める. 企業が時刻 $t$ 以降最 適な意思決定を行った場合の累積期待費用を $F_{t}(\mathrm{US} \$ / \mathrm{kW})$ とすると， $F_{t}(\mathrm{US} \$ / \mathrm{kW})$ は離散近 似した次のベルマン方程式に従う [2].

$$
\begin{array}{ll}
F_{t}=\min \left[V_{\text {gas }, t}, V_{\text {gas_ccs }, t}, V_{\text {coal }, t}, V_{\text {coal_ccs }, t}, 8760 C F \cdot C_{a g e} \cdot \Delta t+E\left[F_{t+\Delta t}\right] \cdot \exp (-r \Delta t)\right] \\
F_{t}=\min \left[V_{\text {gas }, t}, V_{\text {gas_ccs }, t}, 8760 C F \cdot C_{\text {age }} \cdot \Delta t+E\left[F_{t+\Delta t}\right] \cdot \exp (-r \Delta t)\right] & (0 \leq t \leq 4) \\
F_{t}=\min \left[V_{\text {gas }, t}, V_{\text {gas_ccs }, t}\right] & (t=6)
\end{array}
$$


表 1: 想定した電源の各パラメータ

\begin{tabular}{|c|c|c|c|c|c|}
\hline & \multirow{2}{*}{$\begin{array}{c}\text { 現保有石炭火力 } \\
-\end{array}$} & \multicolumn{2}{|c|}{ 新規石炭火力 } & \multicolumn{2}{|c|}{ 新規ガス火力 } \\
\hline & & CCS なし & CCS 付き & CCS なし & CCS 付き \\
\hline 送電端発電効率 [LHV](\%) & $31.5 \%$ & $41.1 \%$ & $34.8 \%$ & $57.0 \%$ & $50.5 \%$ \\
\hline $\mathrm{CO}_{2}$ 排出原単位 $\left(\mathrm{kgCO}_{2} / \mathrm{MWh}\right)$ & 1,081 & 828 & 98 & 355 & 40 \\
\hline 設備利用率 $(\%)$ & $85 \%$ & $85 \%$ & $85 \%$ & $85 \%$ & $85 \%$ \\
\hline 燃料コスト (US\$/GJ) & 3.4 & 3.4 & 3.4 & $P_{1}$ & $P_{1}$ \\
\hline 資本費 $(\mathrm{US} \$ / \mathrm{kW})$ & - & 2,134 & 3,838 & 1,069 & 1,951 \\
\hline 燃料費 (US\$/MW) & 38.9 & 29.8 & 35.2 & - & - \\
\hline 運転維持費 $(\mathrm{US} \$ / \mathrm{MW})$ & 11.0 & 6.0 & 13.0 & 4.5 & 7.3 \\
\hline
\end{tabular}

ただし, $V_{\text {gas }, t}, V_{\text {gas_ccs,t }}, V_{\text {coal }, t}, V_{\text {coal_ccs,t }}(\mathrm{US} \$ / \mathrm{kW})$ は時刻 $t$ において, ガス火力, ガス火 力 $+\mathrm{CCS}$ ，石炭火力，石炭火力 $+\mathrm{CCS}$ 一投資すると決定した場合のそれぞれの期待費用であ り静的な解析解にて計算できる. $C F(\%)$ は設備利用率, $C_{a g e}(\mathrm{US} \$ / \mathrm{kWh})$ は現保有石炭火力 の運転維持費と燃料費の合計, $r(\% /$ 年 $)$ は割引率, $\Delta t$ (年) は 1 ステップ期間である. (3) 式は $1(\mathrm{~kW})$ に規格化しており，8760(h/年) は年間の総時間, $8760 C F$ は $1(\mathrm{~kW})$ 当りの年間発電電 力量である.

$F_{t+\Delta t}$ は $\Delta t$ 後の累積期待費用であり, (1) 式の幾何ブラウン運動を対数変換し Cox-Miller モ デル $[1]$ を拡張した等幅二変数格子モデルにより計算した. 時刻 $t$ に関して後ろ向きに累積期待 費用 $F_{t}$ を算出し待機・投資の閾值を求めた [18]. 時間ステップ $\Delta t$ は約一週間とした.

\section{5 パラメータの設定}

電源の費用については NEA[9] を参考に国際的に標準的な数值とした（表 1）。石炭価格は地 域差異も大きいが，ここでは国際取引価格を参照し時系列的な変化はないものと想定した ${ }^{8}$.

ガス価格 $P_{1}$, 炭素価格 $P_{2}$ については，過去の推移 [10] や各種将来見通し [5] などを参考に， ガス価格 $P_{1}$ の期待変化率 $a_{1}$, ボラティリティ $b_{1}$ をそれぞれ $1.5(\% /$ 年 $), 0.27$, 炭素価格 $P_{2}$ の期 待変化率 $a_{2}$, ボラティリティ $b_{2}$ をそれぞれ $3.2(\% /$ 年 $), 0.34$ とした. 天然ガスは石炭に比べ単 位熱量あたりの $\mathrm{CO}_{2}$ 排出が少なく，また EUETS でもガス価格上昇に伴い炭素価格が高止まり したことから，これら変数間に若干の正の相関 0.2 があるとした。割引率は $5(\% /$ 年 $)$ とした。

8石炭価格は 2008 年に急騰したがその後は従来の価格帯に戻った [10]. 本稿では簡素化のため石炭価格を表 1 の通 り 3.4(US\$/GJ) と固定したが，石炭価格の不確実性の考慮，ガス価格や炭素価格との相関係数の設定など含め今後の 課題である. 


\section{3 結果}

以上の想定の下，期待費用が最小となる待機・投資の閾值を数值計算により求めた．結果を 図 2-3 に示す. 図 2-3 では横軸をガス価格 $P_{1}$, 縦軸を炭素価格 $P_{2}$ とした. 左列の図は「キャッ プ予見ケース」，右列の図は「キャップ不確定ケース」の結果である.

時系列として見た場合の結果について整理する. $t=0$ では基本的に待機領域が広範に広がっ ており, 状況がかなり明確な場合を除き直ちに投資決定することはない. 石炭 (+CCS) を選択 可能な最終時点から 1 年前に当る $t=3$ でもこの状況は大きく変わらず，引き続き待機領域が 大きい，例えば，ガス価格が中庸であれば炭素価格が $65\left(\mathrm{US} \$ / \mathrm{tCO}_{2}\right)$ を超えても待機が選択さ れる ${ }^{9}$. 以上のように待機領域が大きい理由は, 発電効率が低く維持費もかかる現保有の石炭火 力を稼働し続けてでも，待機し新たな状況に合わせて投資判断した方がより低い期待費用とな るためである.

石炭 $(+\mathrm{CCS})$ を選択可能な最終時点 $t=4$ では急速に待機領域は狭まり, 今回の設定パラメー タの下ではガス価格が $8(\mathrm{US} \$ / \mathrm{GJ})$ を超える範囲で石炭 $(+\mathrm{CCS})$ が選択される。なお，今回は 現保有の石炭火力は遅くとも $t=8$ 時点で稼働を止める必要があるため, $t=4$ で石炭 $(+\mathrm{CCS})$ が選択されない限りその後は何れガスを燃料とした電源が入ることとなる.また $t=6$ ではガ ス，ガス $+\mathrm{CCS}$ の何れかの二者択一となる.

次に「キャップ予見ケース」と「キャップ不確定ケース」の比較を行うと, まず各領域が炭素 価格の高い方にシフトしている（例えば $t=4$ での石炭, 石炭 $+\operatorname{CCS}$ の閾值）。また, CCS を 付加しないガス，石炭への投資領域がやや拡大している（例えば $t=3$ でのガス，石炭）. これ は「キャップ不確定ケース」において石炭といった排出量の多い電源を選択することで将来よ り多くの無償キャップを獲得する可能性がある一方，CCS 投資を行うと得られる無償キャップ が切り下げられる可能性があるためである.

キャップ水準による影響をより明確に考察するため, $t=10 \sim 25$ のみ確率 1.0 で過去の排出 に基づくキャップ割当（グランドファザリング）が行われる場合, 即ち確実に実排出分の無償 キャップを得られる場合の結果 $(t=3$ 時点) を図 4 に示す. 図 3 の $t=3$ 時点の結果と比較し, より CCS が不利となることが分かる。このように，グランドファザリングの可能性が上昇する と CCS 投資がより選択されにくくなる.

\section{4 考察とまとめ}

比較のため一般に議論の基礎データとして多用される NPV に基づくブレークイーブンコス 卜（閾值）を図 5 に示す。図 5 は，ガス火力のリードタイムを 4 年とした以外は本稿でのパラ パラメータを利用している。図 5 は IEA [4] などと比較しより低位の炭素価格で CCS 投資が有 利となるが，これは本稿において今後 $3.2(\% /$ 年) で炭素価格が上昇し，また炭素回収の費用し

\footnotetext{
${ }^{9} t=3$ においてガス価格が 10(US\$/GJ) の場合, 炭素価格が 200(US\$ $\left./ \mathrm{tCO}_{2}\right)$ であっても待機が選択されること, さらにはより高い炭素価格であっても待機領域は存在し続けることを別途確認した（「キャップ予見ケース」,「キャップ 不確定ケース」の両ケースにて）.
} 

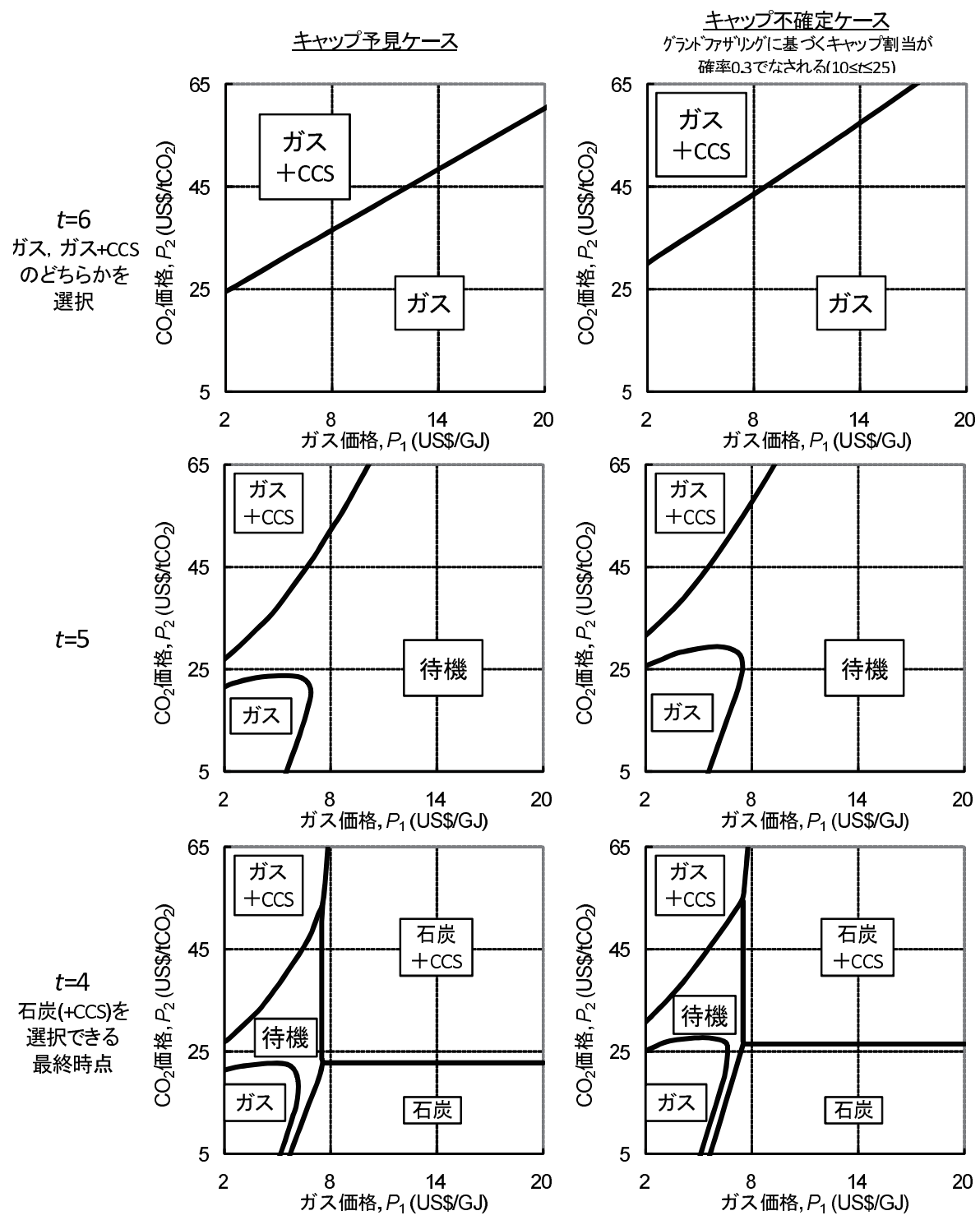

図 2: 待機と投資の閾值の結果 (1)

(左図: キャップ予見ケース，右図: キャップ不確定ケース) 

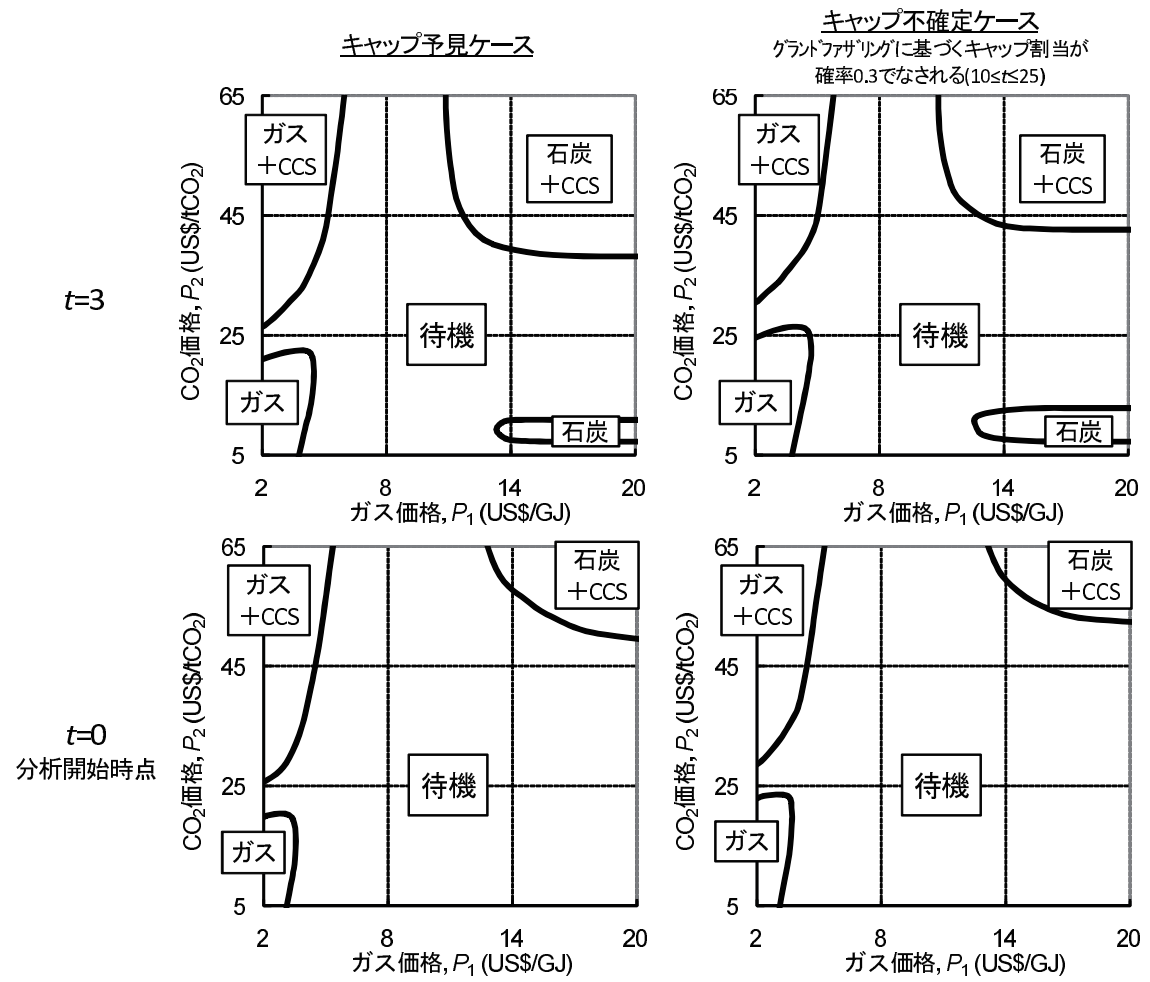

図 3: 待機と投資の閾值の結果 $(2)$

(左図: キャップ予見ケース, 右図: キャップ不確定ケース) 


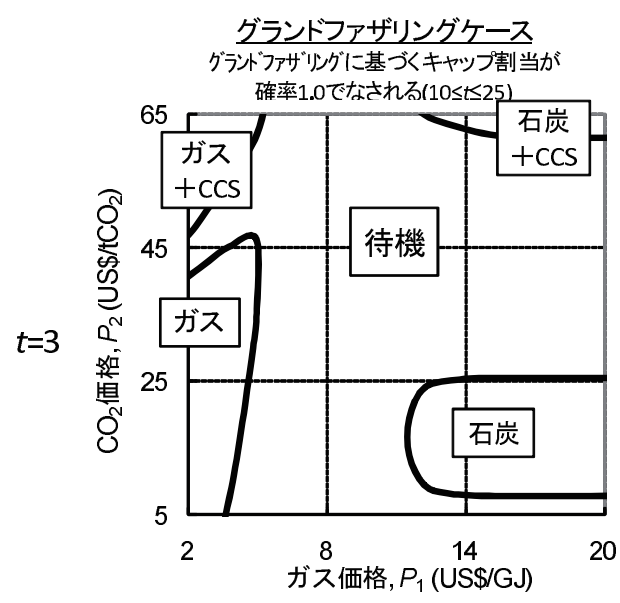

図 4: 待機と投資の閾值の結果 $(t=3)$

か計上していないことによる（EOR 向けに $\mathrm{CO}_{2}$ は外販され正味で炭素輸送以下の費用負担は 発生しないという CCS 投資に有利な条件を本稿では想定）。

本稿は，ガス価格と炭素価格の不確実性を明示的に考慮しつつ，新規電源への更新と待機と を相互に比較した（図 2-3 左）。その結果，待機が最適となる領域が極めて広く早期の電源更 新や CCS 投資はなされにくいことを示した. さらに，キャップ水準の不確実性（過去の排出量 に基づくキャップ割当の可能性）を考慮すると，CCS 投資がよりなされにくくなることを示し た（図 2-3 右，図 4).

具体的に，例えば $45\left(\mathrm{US} \$ / \mathrm{tCO}_{2}\right)$ という炭素価格においてに $\mathrm{NPV}$ に基づく図 5 を前提とす ると CCS 投資は十分な経済合理性があり $\mathrm{CO}_{2}$ の大幅削減が促されるはずであるが，その一方 で現実の複雑性を考慮した図 2-4 を前提とすると $45\left(\mathrm{US} \$ / \mathrm{tCO}_{2}\right)$ であっても直ちに CCS 投資 がなされるにはなお不十分で数十 $\left(\mathrm{US} \$ / \mathrm{tCO}_{2}\right)$ 程度高い炭素価格が少なくとも必要となる.

一般に，NPVの結果，あるいは完全予見を前提としたエネルギーモデル分析により算出した 炭素価格を基にキャップ・アンド・トレードの議論がなされが，むしろ企業は燃料価格や（明 に暗に受ける）炭素価格の不確実性，さらにキャップ・アンド・トレードを施行した場合には キャップ水準の不確実性にさらされるのが現実であるため, このような現実の複雑性を考慮し た上での議論も同時に行っていく必要がある，また，早期の CCS 投資を促すためにも，このよ うなキャップ・アンド・トレードという制度の特質を踏まえつつ, CCS 投資促進のための各種 政策誘導措置 [3] について議論していくことが有効であると言える.

今後の課題として, 石炭価格や電力価格の不確実性の考慮, 電力の外販/外部調達の選択肢の 考慮, 電源 (+ CCS ) の資本費, 運転維持費, 稼働率, 各種リスク負担の不確実性の考慮, パ ラメータの精緻化, 実証分析, 感度解析が挙げられる. 


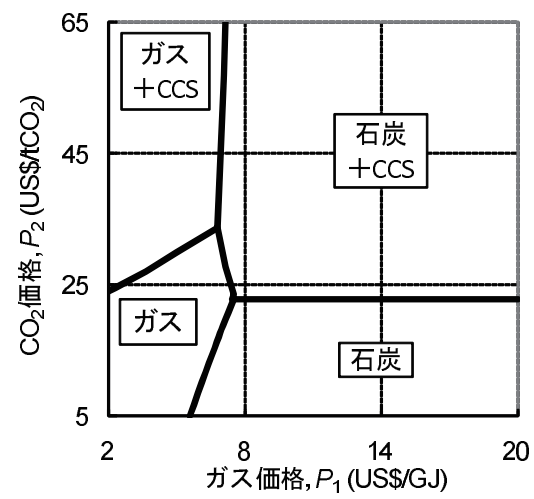

図 5: NPV に基づく電源選択の閾值

(ガス $(+\mathrm{CCS})$ のリードタイムを 4 年として計算, 32 年稼働)

\section{参考文献}

[1] Cox, D. R. and Miller, H. D. (1965). The Theory of Stochastic Processes. Chapman and Hall, London.

[2] Dixit, A. K. and Pindyck, R. S. (1994). Investment under Uncertainty. Princeton University Press, Princeton.

[3] Hamilton, M. R., Herzog, H. J. and Parsons, J. E. (2008). Cost and U.S. public policy for new coal power plants with carbon capture and sequestration. Proceedings of the 9th International Conference on Greenhouse Gas Control Technologies (GHGT-9), 1, 4487-4494.

[4] IEA (2007). Climate Policy Uncertainty and Invest Risk. In support of the G8 Plan of Action, Paris.

[5] IEA (2008). Energy technology perspectives 2008: Scenarios \& Strategies to 2050, Paris.

[6] IEA (2010). Energy technology perspectives 2010: Scenarios 8 Strategies to 2050, Paris.

[7] IPCC (2007). Climate Change 200\%: Mitigation of Climate Change. Contribution of Working Group III to the Fourth Assessment Report. Cambridge University Press.

[8] Lawson, N. (2008). An appeal to Reason, a Cool Look at Global Warming. Overlook Duckworth, Peter Mayer Publishers, New York.

[9] NEA (2010). Projected Costs of Generating Electricity: 2010 Update. OECD/Nuclear Energy Agency. OECD Publishing, Paris. 
[10] US DOE/EIA. http://www.eia.doe.gov/

[11] Vidas, H., Hugmana, R. and Clapp, C. (2008). Analysis of geologic sequestration costs for the United States and implications for climate change mitigation. Proceedings of the 9th International Conference on Greenhouse Gas Control Technologies (GHGT-9), 1, 4281-4288.

[12] 秋元圭吾 (2007). “排出権取引について”. (財) 地球環境産業技術研究機構 (RITE) システ ム研究グループホームページ.

[13] 岡敏弘, 山口光恒 (2007). “EU 排出権取引制度 (EUETS) の研究”. 中央環境審議会・産業 構造審議会合同会議資料.

[14] 小田潤一郎 (2006). “競合電源と温室効果ガス”. 日本リアルオプション学会 2006 年研究発 表大会予稿集, 88-91.

[15] 杉山大志 (2008).「続これが正しい温暖化対策, プレッジ・アンド・レビューによる将来枠 組み」.エネルギーフォーラム。

[16] 地球環境産業技術研究機構 (2008).「RITE DNE21+と IEA ETP2008 シナリオの比較, 平 成 20 年 7 月 22 日」. (財) 地球環境産業技術研究機構 (RITE) システム研究グループホー ムページ.

[17] 諸富徹, 鮎川ゆりか (2007).「脱炭素社会と排出量取引：国内排出量取引を中心としたポ リシー・ミックス提案」。日本評論社.

[18] 森平爽一郎, 小島裕 (1997).「コンピュテーショナルファイナンス」. 朝倉書店. 